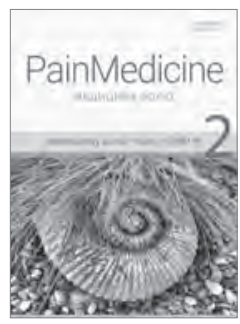

\title{
Зв'язок між показниками вертебробазилярного кровотоку та стабілометрії у пацієнтів з периферичним головокружінням і дегенера- тивними змінами шийного відділу хребта
}

\author{
${ }_{1,2}$ Колісник П. Ф., 1,2 Лісков Я. П., ${ }^{1,2}$ Колісник С. П., ${ }^{2}$ Колісник В. І., \\ ${ }^{1}$ Вінницький національний медичний університет імені М. І. Пирогова, м. Вінниця, Україна \\ ${ }^{2}$ Центр медичної реабілітації та спортивної медицини, м. Вінниця, Україна
}

Актуальність. Поширеність головокружіння складає від 4 до $7 \%$ дорослого населення. За даними Yardley L. (1998), із 20 тисяч опитаних людей працездатного віку до $30 \%$ страждали на головокружіння понад 5 років, що значно погіршувало якість життя та підвищувало ризик падіння. До найпоширеніших причин периферичного головокружіння відносяться: доброякісне пароксизмальне позиційне головокружіння, хвороба Меньєра, вестибулярний нейроніт і порушення кровотоку у вертебробазилярному басейні (ВББ). За даними ЯхноН. Н. (2005), причинами порушення кровотоку ВББ $€$ стеноз магістральних судин, вроджені особливості будови судинного русла, мікроангіопатії, синдром підключичного обкрадання, компресія хребтових артерій патанатомічно зміненими структурами в шийних сегментах, защемлення потиличного нерва, гостра травма шийного відділу хребта, артеріїти, антифосфоліпідний синдром, спазм підпотиличних м'язів тощо. Основними методами дослідження є: МРТ в судинному режимі, УЗД судин шиї та голови, реоенцефалографія (РЕГ), стабілометрія, електроністагмометрія тощо. Хоча залежність ризику падіння від постуральних функцій доведена, але зв'язок між показниками базилярного кровотоку та стабілометрії потребує вивчення.

Мета: вивчити зв'язок між реографічними показниками кровотоку в ВББ та даними стабілометричного аналізу у пацієнтів з периферичним головокружінням та дегенеративними змінами шийного відділу хребта, оцінити кореляційний зв'язок між даними РЕГ та стабілометрії.

Матеріали і методи: у дослідження було включено 16 пацієнтів 3 периферичним головокружінням віком 23-63 $(42,07 \pm 13,6)$ років. Реєстрацію РЕГ виконували в стандартних (фронто- мастоїдальному та окципіто-мастоїдальному) відведеннях з різницею базового імпедансу до 10 Ом. Зміни кровотоку досліджувалися у стандартному положенні голови. Показники постуральної стійкості досліджувалися за допомогою стабілометрії у вертикальному положенні з відкритими очима. Статистичну обробку проводили за допомогою програми SPSS. Для оцінки кореляції використовували коефіцієнт кореляції Пірсона. Достовірність різниці рівня ознаки в групах розраховано за допомогою критерію Манна - Уїтні.

Результати. Встановлено достовірну різницю показників відхилення центру мас у сагітальній площині у пацієнтів 3 головокружінням $(U=10,5$; $\mathrm{p}=0,01)$. Спостерігався прямий кореляційний зв'язок середньої сили між коефіцієнтом асиметрії кровотоку у ВББ та відхиленням центру мас у сагітальній площині $(r=0,56 ; p \leq 0,05)$.

Висновки. Отримані результати свідчать про прямий кореляційний зв'язок середньої сили між коефіцієнтом асиметрії кровотоку у ВББ та відхиленням центру мас в сагітальній площині у пацієнтів 3 периферичним головокружінням, що може свідчити про зв'язок порушень кровотоку в ВББ 3 периферичним головокружінням і потребує подальшого дослідження.

Перспективи подальших досліджень. Дослідження $€$ фрагментом дисертаційної роботи та науково-дослідної роботи кафедри. Триває обстеження пацієнтів і дослідження між показниками вертебробазилярного кровотоку та стабілометрії.

Ключові слова: периферичне головокружіння, стабілометрія, реоенцефалографія (РЕГ), вертебробазилярний басейн (ВББ).

Конфлікт інтересів: автори заявляють про відсутність конфлікту інтересів. 